\title{
The impact of COVID-19 on China's regional economies and industries
}

\author{
WU Feng ${ }^{1,2}$, LIU Guijun ${ }^{1,2}$, GUO Naliang ${ }^{1,2}$, LI Zhihui ${ }^{1,2}$, DENG Xiangzheng ${ }^{1,2}$ \\ 1. Key Laboratory of Land Surface Pattern and Simulation, Institute of Geographic Sciences and Natural Re- \\ sources Research, CAS, Beijing 100101, China; \\ 2. University of the Chinese Academy of Sciences, Beijing 100049, China
}

\begin{abstract}
Scientifically assessing the economic impact of major public health emergencies, containing their negative effects, and enhancing the resilience of an economy are important national strategic needs. The new coronavirus disease (COVID-19) has, to date, been effectively contained in China, but the threat of imported cases and local risks still exist. The systematic identification of the virus's path of influence and intensity is significant for economic recovery. This study is based on a refined multi-regional general equilibrium analysis model, which measures the economic and industrial impacts at different epidemic risk levels in China and simulates development trends and the degree of damage to industries and the economy under changes to supplies of production materials and product demand. The results show that, at the macroeconomic level, China's GDP will decline about $0.4 \%$ to $0.8 \%$ compared to normal in 2020 , with an average drop of about $2 \%$ in short-term consumption, an average drop in employment of about $0.7 \%$, and an average increase in prices of about $0.9 \%$. At the industry level, the epidemic will have the greatest short-term impact on consumer and laborintensive industries. For example, the output value of the service industry will fall $6.3 \%$ compared to normal. Looking at the impact of the epidemic on the industrial system, the province most affected by the epidemic is Hubei, which is the only province in China in the level-1 risk category. As the disease spread outward from Hubei, there were clear differences in the main industries that were impacted in different regions. In addition, simulation results of recovery intensity of regional economies under the two epidemic response scenarios of resumption of work and production and active fiscal stimulus policies show that an increase in fiscal stimulus policies produces a $0.3 \%$ higher rate of gross regional product growth but it causes commodity prices to rise by about $1.8 \%$. Measures to resume work and production offer a wider scope for industrial recovery.
\end{abstract}

Keywords: COVID-19; economic system impact; industrial impact; zoning classification; multi- region general equilibrium; system resilience; recovery strategy

Received: 2020-12-01 Accepted: 2021-01-29

Foundation: National Natural Science Foundation of China, No.72042020

Author: Wu Feng (1979-), PhD and Associate Professor, specialized in complex system modeling and sustainable development. E-mail: wufeng@igsnrr.ac.cn

*Corresponding author: Li Zhihui (1990-), PhD, specialized in water and soil resource policy and management. 


\section{Introduction}

In addition to affecting human health, major public health emergencies inevitably impact a country's economy. The negative effects of the novel coronavirus epidemic (hereafter "COVID-19") on industrial production, household consumption and trade have gradually emerged (McKibbin and Fernando, 2020; Binder, 2020). COVID-19 and severe acute respiratory syndrome (SARS) are similar and comparable. In 2003, SARS caused China's economy to contract by approximately $0.5 \%$ (Zeng and Feng, 2004). China is currently in a critical stage of high-quality development, and COVID-19 has had significant short-term impacts on its economy and industry at the macro scale and on individuals at the micro scale (He et al., 2020; Shao, 2020). From a macroeconomic perspective, the circulation of production materials, such as labor and capital, has been hindered, resulting in a sharp drop in production capacity. This has restricted consumption, investment, and exports on the demand side, causing prices to rise (Wen et al., 2020). From the perspective of industry, COVID-19 has severely impacted sectors such as transportation, retail, tourism, catering, real estate, and construction (Huang, 2020). Looking at the micro scale of individuals, payments of fixed expenses, such as rent, and the interruption of income caused by production stagnation have had a double impact on enterprises (Tang et al., 2009). The impact of COVID-19 on China's economy is very different to the impact the SARS epidemic had in 2003 (Lee and McKibbin, 2004). Research on the economic impact of major public health emergencies can aid national disease containment and economic development and recovery efforts, and it is a hot topic of research in emergency management.

Containment policies and economic measures in response to global and national public health emergencies are a focus of contemporary research. Assessments of the impacts on the global economic system are mainly based on data on trade and capital flows between countries and analyze the effects of the epidemic on products in different industries and on trade links between countries (Lee and McKibbin, 2004; McKibbin and Sidorenko, 2006; Nicola et al., 2020). On the supply side, COVID-19 containment measures have restricted the flow of domestic labor and production materials, making it difficult for companies to resume work and affecting global supply chains. The impact on international supply chains has hindered multiple links in the global industrial division of labor system, which has indirectly affected the global economy (Deb et al., 2020; Lenzen et al., 2020; Wang, 2020). On the demand side, the epidemic has led to a decline in demand for international products, impeded import and export trade, and affected global, national and regional industry chains (Sun, 2020).

The World Economic Outlook released by the International Monetary Fund in April 2020 predicted that global real GDP would fall by $3 \%$, and the WTO predicted that global merchandise trade would decline by $13 \%$ to $32 \%$ (Barichello, 2020). As a result of continuous global economic integration, major public health events have an increasingly global impact (Geoffard and Philipson, 1996). National-scale research focuses on macroeconomics and changes in the production scale of various industries and regions due to public health emergencies (Cuddington and Hancock, 1995; Anand et al., 1999; Dixon et al., 2002). In the past, research on the economic impact of epidemics tended to concentrate on disease-related medical costs and costs caused by diseases (Sachs, 2001; Keogh-Brown et al., 2010; Smith et al., 2011). The spread of COVID-19 has affected many industrial sectors, however, and 
focusing only on the medical and health sectors has limitations (Siu and Wong, 2004; Smith et al., 2019). Some researchers have found using input-output analysis that China's response measures and suppressed demand elasticity can limit the long-term impact of the epidemic on the economy, but in the short term, service industries such as transportation, tourism and entertainment will decline by as much as $18 \%$ (Duan et al., 2020). In addition to the impact on various industrial sectors, the systemic effects of the epidemic on regional economies have also received considerable attention. For example, an analysis of the impact of isolation measures on household consumption patterns and intensity have been included in studies on the economic impact of COVID-19 (Lee and Warner, 2006; Smith et al., 2019). Some researcherss have also conducted impact analyses of changes in labor and other means of production and changes in household consumption, such as analyzing the impact on the macroeconomy of labor force population loss as well as inter-regional mobility restrictions due to the spread and impact of COVID-19 (Zhou and Jiang, 2020). Other researchers have analyzed spatial differences in the impact of COVID-19 on regional economies based on factors such as the degree of impact of the epidemic and the historical GDP growth (Zhu et al., 2020). To identify the epidemic's impact on the economic system, it is necessary to systematically assess the different impacts on the economy by dividing it into regions, risk categories and industries, so as to explore adaptability and recovery strategies under this three-way division strategy.

Quantitative research on the economic impacts of major public health events can provide an empirical basis for improving the resilience of an economic system. Looking at quantitative analysis methods, Computable General Equilibrium (CGE) models are widely used to analyze the economic impacts of major public health events (such as SARS and H1N1) (Kambou et al., 1992; Yang and Chen, 2009; Smith and Keogh-Brown, 2013; Roos, 2013; Wen et al., 2020). In analyses of the impact on the global economic system, the G-Cubed multi-country, multi-sector intertemporal general equilibrium model is used, as it takes into account the speed of global trade and capital flows, and it portrays the different impacts of epidemics on macroeconomic development trends of various countries and the industrial economy (Lee and McKibbin, 2004). Impact analyses at the national level have used dynamic long-term economic forecasting models (Gohin and Rault, 2013; Xie et al., 2013) and static models to examine regional differences (Smith et al., 2011). The former incorporate capital accumulation, analyze capital changes as a result of the disturbance of an epidemic, and make long-term impact forecasts. To distinguish between instantaneous shocks and continuous effects, some researchers have created a quarterly computable general equilibrium model to capture the short-term effects of epidemics at the quarter-year time scale (Dixon et al., 2010). Research involving static models focuses on the impact of regional differences in epidemic intensity. Other researchers have used a multi-regional static computable general equilibrium model to portray the intensity of trade and transportation between regions within a country and to analyze spatial and temporal differences in the impacts on sub-regional and administrative levels, to help design economic recovery policies (Horridge and Wittwer, 2008; Horridge, 2012; Jiang et al., 2016).

Past studies have analyzed the economic impacts of major public health events at different scales and in different industrial sectors, but there is a lack of research on the economic impacts of epidemics at the national scale. The level of risk and response measures to an 
epidemic in each province, municipality or autonomous region is different, and regional economic systems obviously differ. As such, this article improves the multi-regional computable general equilibrium analysis model for China (TERM-China) to study the economic impact of COVID-19 intensity and regional differences in containment efforts in different regions and at different risk levels. This study then analyzes the impact of COVID-19 on China's main industries based on the 2017 China Multi-Regional Input-Output Tables and statistical data from 2019. The focus is on identifying sectors directly impacted by COVID-19, such as tourism, catering, retail, transportation, logistics and public health. At the regional level, consideration is given to differences in epidemic levels, circulation of production materials and transportation controls, and the different impacts of COVID-19 on economic and industrial development, with a view to providing an empirical and accurate basis from which to formulate policies that will facilitate economic recovery.

\section{Models and data}

Public health emergencies have short-term macroeconomic impacts, so this study uses a short-term static TERM-China model to simulate its effects. The static TERM-China model is based on the CGE framework. It focuses on supply-side production material impacts, but it can also analyze the impact of changes on the demand side. In addition, it can describe optimization behaviors and system differences of inter-provincial commodity circulation and economic entities (producers, households, investors, importers and exporters, and the government), providing an analysis platform for studying China and the relationship between provinces and between regions (Figure 1) (Horridge, 2012).

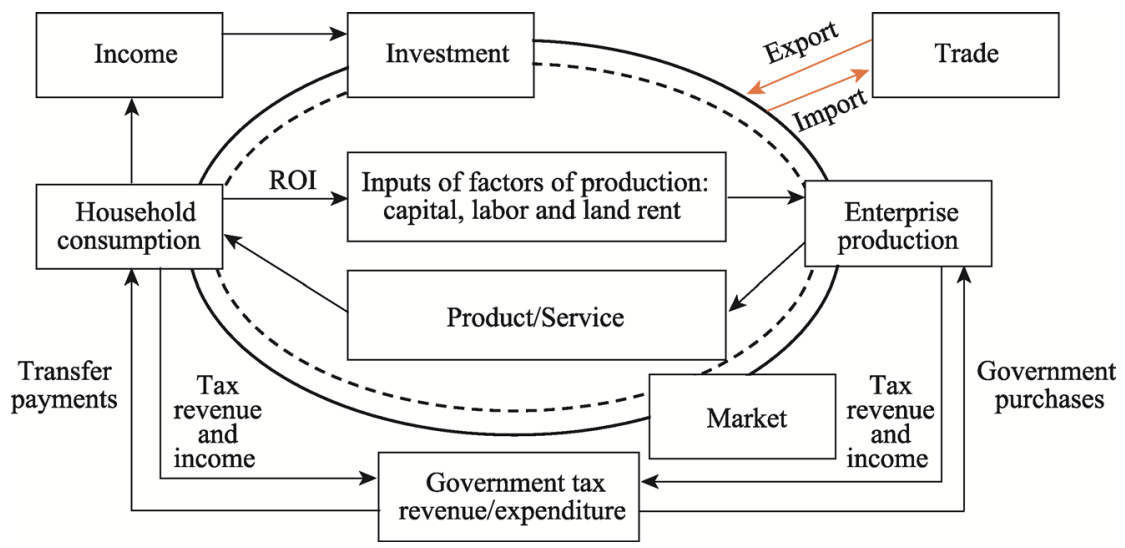

Figure 1 The enormous regional model (TERM) framework

The macro closure of the economic system model directly affects the simulation results, and the closure is essentially a choice of macroeconomic theory. Based on the static TERM-China model (Horridge and Wittwer, 2008; Horridge, 2012; Jiang et al., 2016), this study chooses a short-term closure, mainly drawing on the conclusions of multiple research institutions and researchers on the impact of the COVID-19 epidemic on the Chinese economy (He et al., 2020; Wen et al., 2020; Zhu et al., 2020). The short-term closure of the TERM-China model includes assumptions such as constant capital stock in industry, inelas- 
tic real wages, regional rate of return and labor mobility between regions (Horridge, 2012; Jiang et al., 2016). Closure research improves the model's fixed assumption that private consumption demand depends on national economic output and government expenditure. In the actual economy, a lack of labor and a suspension of work and production causes idle capital, which leads to a rise in labor prices and in the price of recurring wages as well as an increase in production costs. The original model assumes that capital is fully utilized, and there is a significant drop in the price of capital due to a loss of labor in the production function, which in turn leads to the problem of lower production costs (Dixon and Rimmer, 2010; Xie et al., 2012). As a result, this study uses replacement cost setting to replace capital stock before the epidemic with capital stock after the epidemic, allowing each industry to use less capital than existing capital, thereby inhibiting the decline of capital prices. In addition, the model includes detailed handling of transportation costs and is suitable for simulating the impact of changing railway or highway connections. Because of this, this study improves the model's production module to factor inputs, with the constant elasticity of substitution (CES) production function determining the input ratios of labor, capital and other production materials (formulas 1 and 2):

$$
\begin{gathered}
Z=\left[Y_{l} L^{a}+Y_{k} K^{a}\right]^{1 / a} \\
K U_{i} \leqslant K E_{i}
\end{gathered}
$$

where, $Z$ is output; $L$ is labor input; $K$ is capital investment; $K U_{i}$ is the capital that industry $i$ can use, and $K E_{i}$ is the present capital of industry $i ; Y_{k}$ is capital factors as a proportion of outputs; $a$ is the CES between labor and capital in factor inputs.

The data used in this study includes data on the COVID-19 epidemic and socioeconomic data. COVID-19 data is the latest data released by the National Health Commission of the People's Republic of China, including on severe cases, suspected cases, confirmed cases and the number of people in isolation (the statistical time period is from January 20 to September 3 , 2020). Socioeconomic data includes the input-output tables of 42 departments in 31 provinces, municipalities and autonomous regions in China published by the National $\mathrm{Bu}-$ reau of Statistics in 2012 as well as provincial statistical yearbooks and customs trade and tariff data from 2019. Based on the above data, this study creates a static TERM-China model of 31 provinces, municipalities and autonomous regions in China that includes inter-provincial trade (Hong Kong, Macao and Taiwan are not included due to data reasons).

\section{Impact analysis of COVID-19 and scenario design}

Following the outbreak of the COVID-19 epidemic in China, it spread to all provinces, municipalities and autonomous regions. Localities adopted different response levels according to the development stage and degree of severity of the epidemic. Regions with different risk levels suffered differing economic losses, and the design of zoning and grading scenarios was particularly important. Based on the level of response to the epidemic situation, the number of confirmed cases, the size of the provincial population and inter-provincial population movements, this study uses a ranking system to divide areas into four levels (Table 1). In the ranking calculation, statistical response time (days) of different levels across the country is used as the control time of the province, and it takes into account the number of 
confirmed cases of the epidemic in that place and its ratio to the total number of people in the province (as of September 3, 2020). This is combined with population outflows from Hubei Province to each province to give corresponding weights to different indicator rankings (Verikios et al., 2010; Tu et al., 2020). An overall ranking method is used to rank the whole country (formulas 3 and 4).

$$
\begin{gathered}
R=0.2 * T+0.1 * C r+0.5 * C n+0.2 * M r \\
T=T_{12} * 0.6+T_{23} * 0.4
\end{gathered}
$$

where $R$ is the overall rank; $T$ is the control time rank; $T_{12}$ is the time interval for the risk to fall from level 1 to level 2; $T_{23}$ is the time interval for the risk to fall from level 2 to level 3; $\mathrm{Cr}$ is the rank of confirmed cases as a proportion of population; $\mathrm{Cn}$ is the rank of confirmed cases; and $M r$ is the rank of population outflow as a proportion of the total population. Based on the calculated overall rank, percentage breakpoints are used to determine classification. The top 5\% are level-1 risk areas, the next 30\% are level-2 risk areas, and the next $60 \%$ are level-3 risk areas, and the rest are level-4 areas (Figure 2).

\begin{tabular}{|c|c|c|c|c|c|c|c|}
\hline & $\begin{array}{l}\text { Confirmed cases } \\
\text { (number) }\end{array}$ & $\begin{array}{l}\text { Total popula- } \\
\text { tion (million) }\end{array}$ & $\begin{array}{l}\text { Levels 1-2 } \\
\quad \text { (days) }\end{array}$ & $\begin{array}{l}\text { Levels 2-3 } \\
\quad \text { (days) }\end{array}$ & $\begin{array}{l}\text { Levels 1-3 } \\
\quad \text { (days) }\end{array}$ & $\begin{array}{c}\text { Outflow of } \\
\text { population }(\%)\end{array}$ & $\begin{array}{l}\text { Risk level } \\
\text { classification }\end{array}$ \\
\hline Hubei & 68139 & 59.17 & 99 & 44 & 143 & 0.00 & 1 \\
\hline Guangdong & 1758 & 113.46 & 32 & 75 & 107 & 8.07 & 2 \\
\hline Zhejiang & 1278 & 57.37 & 39 & 21 & 60 & 2.97 & 2 \\
\hline Henan & 1276 & 96.05 & 54 & 47 & 101 & 19.22 & 2 \\
\hline Hunan & 1019 & 68.99 & 47 & 21 & 68 & 16.82 & 2 \\
\hline Anhui & 991 & 63.24 & 32 & 19 & 51 & 6.74 & 2 \\
\hline Beijing & 935 & 21.54 & 97 & 37 & 134 & 1.44 & 2 \\
\hline Jiangxi & 935 & 46.48 & 48 & 8 & 56 & 7.86 & 2 \\
\hline Shanghai & 913 & 24.24 & 60 & 46 & 106 & 1.36 & 2 \\
\hline Heilongjiang & 948 & 37.73 & 39 & 21 & 60 & 0.45 & 3 \\
\hline Chongqing & 583 & 31.02 & 46 & 14 & 60 & 8.40 & 3 \\
\hline Xinjiang & 902 & 24.87 & 31 & 11 & 42 & 0.24 & 3 \\
\hline Jiangsu & 665 & 80.51 & 31 & 32 & 63 & 3.84 & 3 \\
\hline Shandong & 831 & 100.47 & 44 & 59 & 103 & 2.18 & 3 \\
\hline Sichuan & 656 & 83.41 & 33 & 28 & 61 & 4.14 & 3 \\
\hline Fujian & 384 & 39.41 & 33 & 22 & 55 & 2.52 & 3 \\
\hline Shaanxi & 373 & 38.64 & 0 & 0 & 34 & 3.28 & 3 \\
\hline Hainan & 171 & 9.34 & 0 & 0 & 32 & 0.89 & 3 \\
\hline Hebei & 365 & 75.56 & 97 & 37 & 134 & 1.87 & 4 \\
\hline $\begin{array}{l}\text { Inner } \\
\text { Mongolia }\end{array}$ & 261 & 25.34 & 0 & 0 & 31 & 0.26 & 4 \\
\hline Tianjin & 230 & 15.60 & 97 & 37 & 134 & 0.23 & 4 \\
\hline Liaoning & 263 & 43.59 & 0 & 0 & 28 & 0.46 & 4 \\
\hline Guangxi & 257 & 49.26 & 0 & 0 & 31 & 1.86 & 4 \\
\hline Shanxi & 203 & 37.18 & 30 & 15 & 45 & 1.20 & 4 \\
\hline Gansu & 169 & 26.37 & 0 & 0 & 27 & 0.71 & 4 \\
\hline Yunnan & 199 & 48.30 & 0 & 0 & 31 & 1.12 & 4 \\
\hline Ningxia & 75 & 6.88 & 34 & 68 & 102 & 0.07 & 4 \\
\hline Jilin & 157 & 27.04 & 32 & 23 & 55 & 0.28 & 4 \\
\hline Guizhou & 147 & 36.00 & 0 & 0 & 30 & 1.40 & 4 \\
\hline Qinghai & 18 & 6.03 & 0 & 0 & 32 & 0.08 & 4 \\
\hline Tibet & 1 & 3.44 & 36 & 22 & 58 & 0.02 & 4 \\
\hline
\end{tabular}

Table 1 Statistics of COVID-19 risk classification in China 


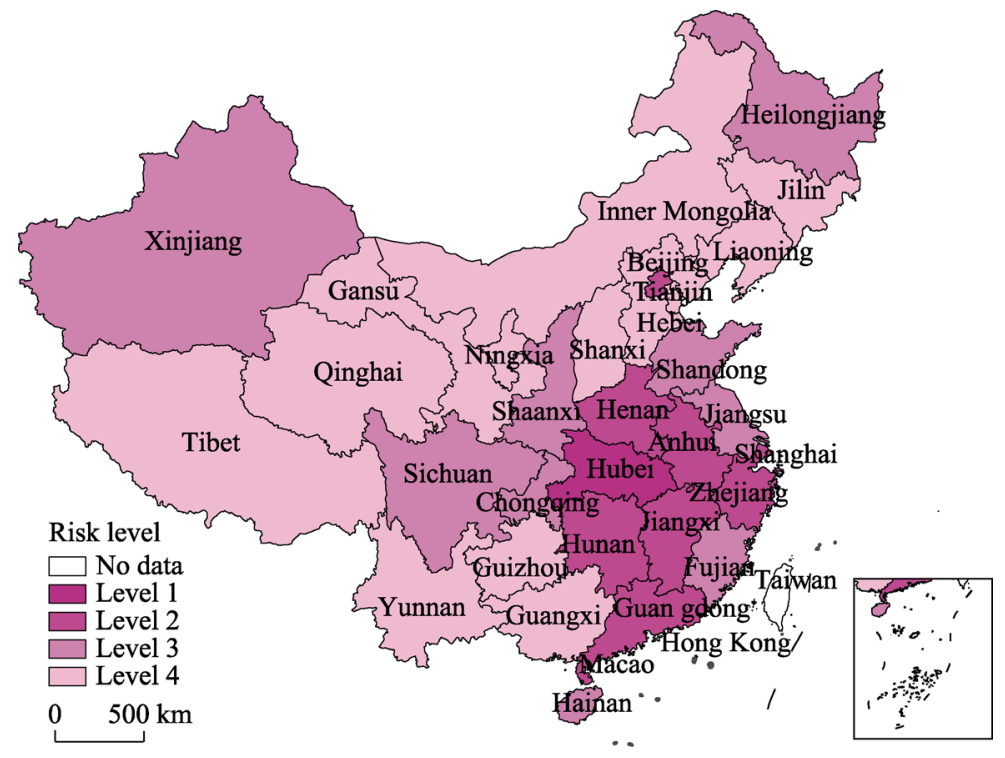

Figure 2 COVID-19 risk classification in China

This study analyzes the economic impact of the COVID-19 epidemic from three aspects: supply, demand and trade. It also considers epidemic response policies to ease economic pressures, and it researches and designs scenarios for getting people back to work and restarting production as well as proactive fiscal policies for different regions and different risk levels. Given that the model simulation time scale is years, the research assumes that economic development will return to the normal level of previous years after August, and it combines national data released from January to July and research conclusions of many institutions and researchers to set the scenario simulation parameters.

On the supply side, COVID-19 prevention and control measures caused companies to delay the resumption of work. According to statistics from the National Health Commission's Migrant Population Service Center, the floating population in Wuhan accounted for about $40 \%$ of the total floating population of Hubei Province in 2018, and significant population movements caused COVID-19 to spread to a large area around Hubei Province. Labor losses due to COVID-19 were mainly indirect losses caused by restricting the movements of workers to contain the virus as well as direct losses caused by illness and death due to the disease. The indirect losses are mainly calculated by determining the working days lost due to epidemic prevention and control efforts and comparing it with the working hours in one year of an individual(Verikios et al., 2010; Verikios et al., 2011; Zhou et al., 2020). The direct losses are determined based on public statistics. The formula for calculating the proportion of lost labor in this study is as follows:

$$
L_{i}=\left(\frac{C t_{i} * N e_{i}}{S W H}+N d_{i}\right) * \frac{1}{N e_{i}} * 100 \%
$$

where $L_{i}$ is the proportion of lost labor of a region; $N e_{i}$ is the total number of employees in the primary, secondary and tertiary sectors of a region; $S W H$ is the hours worked by an individual in one year, calculated at 250 working days per year; $C t_{i}$ is the length of time that the region was under controls, that is, the interval from the highest level of response to the sec- 
ond level of response; and $N d_{i}$ is the number of confirmed cases in that region.

The results show that the proportion of labor losses due to COVID-19 in China's provinces, municipalities and autonomous regions is the highest in Hubei Province and gradually decreases as distance increases from there. Labor losses in Hubei, Hebei, Beijing and Tianjin were relatively large, exceeding 3.2\% during the year, followed by Henan and Shanghai, ranging from $2.0 \%$ to $3.2 \%$ during the year. The majority of provinces were between $1.2 \%$ and $2.4 \%$, and there was little impact in Gansu and Liaoning (Figure 3).

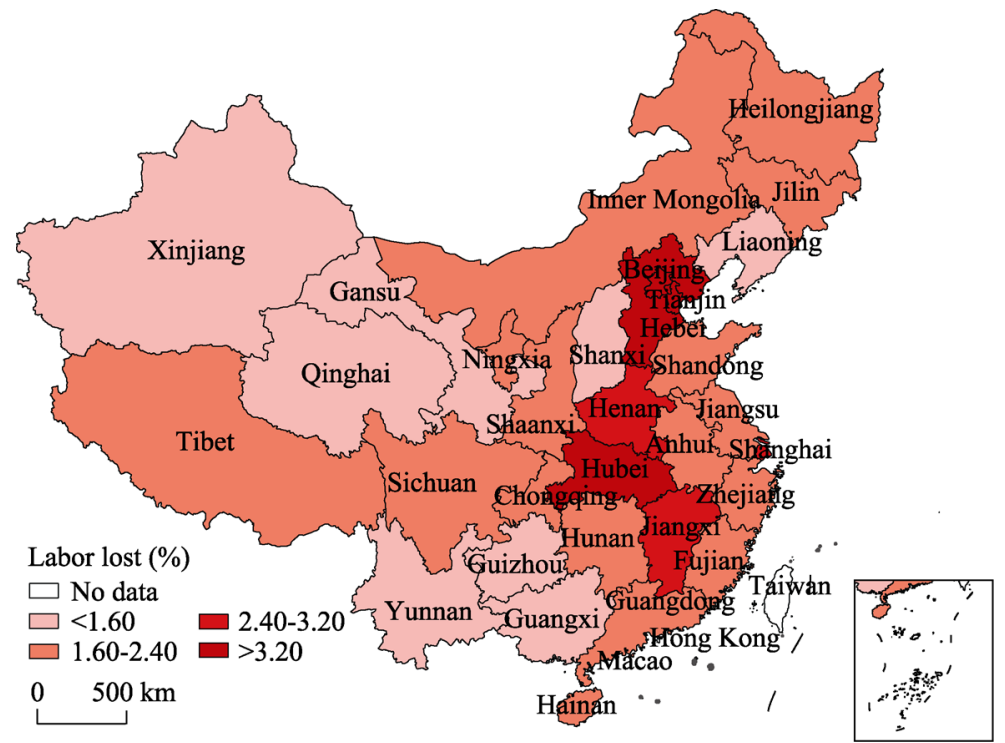

Figure 3 Estimations of labor losses caused by COVID-19 containment measures in China

On the demand side, the epidemic led to a substantial decrease in consumer demand. China's COVID-19 outbreak was during the Spring Festival (Chinese New Year) holiday, which amplified the impact on tertiary industry, though demand in the health and social management, information transmission and technology sectors increased. As a result, in the model, overall household consumption is reduced and demand in some industries is changed. Combining the non-uniformity of residents' annual consumption (Zhou et al., 2020), this study obtains corresponding industrial shock parameters based on the proportion of total retail sales of consumer goods.

In terms of trade, the COVID-19 epidemic had a significant impact on China's import and export trade. The global spread of the virus led to trade restrictions, increasing the cost of China's foreign trade exports and impacting its exporting industries. During the virus outbreak in China, production in enterprises that trade overseas was completely shut down. According to statistics from the General Administration of Customs, China's exports fell by $0.9 \%$ between January and July 2020 . The model assumes a gradual recovery in exports and simulates a $1 \%$ decline in exports for the year.

To control the economic impact of COVID-19, localities introduced different policies and measures that coordinated containment with economic recovery. In terms of getting people back to work and resuming production in different areas and at different risk levels, resumption of work and production is mainly simulated by increasing labor supply, and data released by the Ministry of Transport and Wind database show that the proportion of non-local 
workers who returned to work was about $35 \%-40 \%$. The different durations of control measures in different areas means that there were differences in the recovery of labor supply. As a result, this study assumes that the labor supply recovery rate of level-1 risk areas was $35 \%$, and it was $40 \%$ for risk areas of levels $2-4$. Looking at proactive fiscal policies, these are simulated by increasing government expenditure. The parameters are based on public data of general public expenditures in government budgets in 2020.

Based on the above analysis, simulations in different areas and at different risk levels are carried out under the four impact scenarios of labor supply, transportation, consumption demand and exports, as well as the two adaptive scenarios of restoring labor supply and increasing government expenditure (Table 2).

Table 2 Scenario design and parameters for economic impact and adaptation analysis of COVID-19 epidemic

\begin{tabular}{|c|c|c|c|c|c|c|}
\hline $\begin{array}{l}\text { Scenario } \\
\text { design }\end{array}$ & $\begin{array}{c}\text { Impact } \\
\text { Scenario } 1\end{array}$ & $\begin{array}{c}\text { Impact Scenario } 2 \\
(+ \text { Scenario } 1)\end{array}$ & $\begin{array}{c}\text { Impact Scenario } 3 \\
(+ \text { Scenario } 2)\end{array}$ & $\begin{array}{c}\text { Impact Scenario } \\
4 \\
(+ \text { Scenario } 3)\end{array}$ & $\begin{array}{c}\text { Adaptive } \\
\text { Scenario 1 } \\
(+ \text { Scenario 4) }\end{array}$ & $\begin{array}{c}\text { Adaptive } \\
\text { Scenario } 2 \\
(+ \text { Scenario 4) }\end{array}$ \\
\hline $\begin{array}{c}\text { Shock } \\
\text { conditions }\end{array}$ & $\begin{array}{l}\text { Declining } \\
\text { labor supply }\end{array}$ & $\begin{array}{l}\text { Transportation } \\
\text { controls }\end{array}$ & $\begin{array}{l}\text { Equal decline in indus- } \\
\text { trial demand of all } \\
\text { regions } \\
\text { a. Health and social } \\
\text { work } \\
\text { b. Information trans- } \\
\text { mission and technology } \\
\text { c. Accommodation and } \\
\text { catering } \\
\text { d. Wholesale and retail } \\
\text { f. Entertainment }\end{array}$ & $\begin{array}{l}\text { Equal reduction } \\
\text { in exports of all } \\
\text { regions }\end{array}$ & $\begin{array}{l}\text { Return to work } \\
\text { and production }\end{array}$ & $\begin{array}{l}\text { Government } \\
\text { expenditure }\end{array}$ \\
\hline $\begin{array}{l}\text { Level-1 } \\
\text { areas }\end{array}$ & $-3.20 \%$ & $-53 \%$ & $\begin{array}{l}\text { a. } 18.2 \% \\
\text { b. } 9.7 \%\end{array}$ & $-1 \%$ & $1.12 \%$ & $13.08 \%$ \\
\hline $\begin{array}{c}\text { Level-2 } \\
\text { areas }\end{array}$ & $-2.40 \%$ & $-34 \%$ & c. $-18.0 \%$ & $-1 \%$ & $0.96 \%$ & $18.70 \%$ \\
\hline $\begin{array}{c}\text { Level-3 } \\
\text { areas }\end{array}$ & $-1.60 \%$ & $-30 \%$ & d. $-7.5 \%$ & $-1 \%$ & $0.64 \%$ & $15.00 \%$ \\
\hline $\begin{array}{c}\text { Level-4 } \\
\text { areas }\end{array}$ & $-1.20 \%$ & $-26 \%$ & f. $-9.0 \%$ & $-1 \%$ & $0.48 \%$ & $10.00 \%$ \\
\hline
\end{tabular}

\section{Analysis of results}

\subsection{Macroeconomic effects of COVID-19}

Production structure and scale, length of industrial chains, total demand and demand model, and international trade links are factors that determine the resilience of the Chinese economy to the effects of the COVID-19 epidemic (KPMG China, 2020; Zhou, 2020; Zhou et al., 2020). Looking at the production structure of areas with different risk levels, most of the areas of levels 1 and 2 are located in the Yangtze River Economic Belt, where the secondary and tertiary sectors dominate regional economies, having already basically achieved industrialization and entering the post-industrialization stage, which is dominated by service industries (Wang et al., 2017). Looking at level-3 risk areas, the dominant industry in Heilongjiang, Liaoning and Hainan is agriculture, while the economies of Beijing, Shanghai and Hainan are highly dependent on the development of the tertiary sector. Other level-3 provinces are mostly located in western China, and their economic focus is on energy and resource exploitation and processing. The development of the secondary sector in level-4 
areas lags behind other parts of the country, so many people migrate for work (Figure 4).

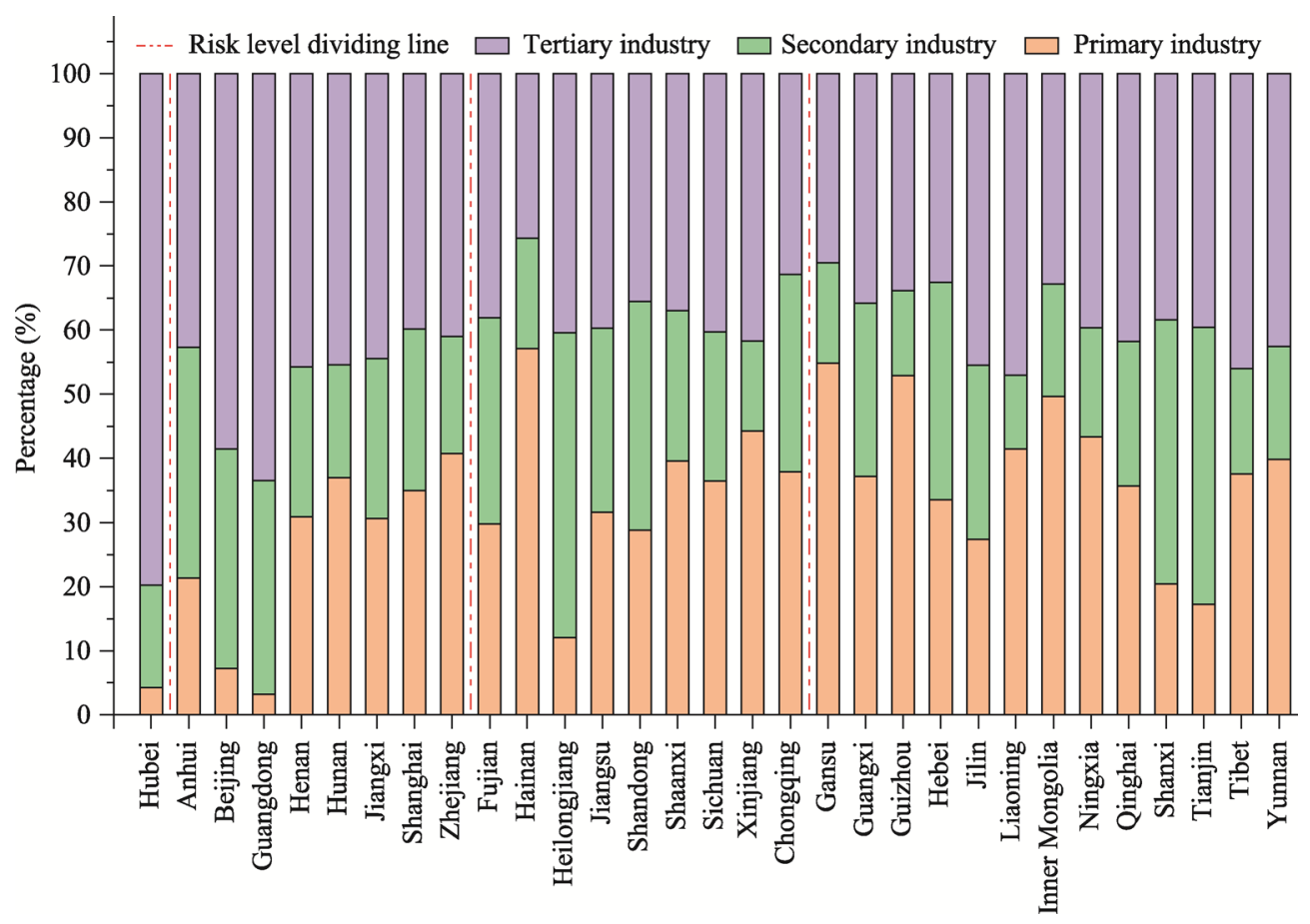

Figure 4 Employment ratios in industrial sectors of each Chinese province in 2019

There are differences in the intensity and direction of macroeconomic effects of COVID-19 on gross regional product (GRP), price levels (CPI), employment, imports, exports and consumption in various areas. The economic impact of COVID-19 was the greatest in Hubei Province, the only level-1 areas. Provinces in the east and southeast were also badly affected, and provinces in the west and northwest regions were less affected (Figure 5). The GRP of the level-1 areas fell by $0.77 \%$, while GRP of level-4 areas fell by $0.24 \%$ (Table $3)$. The reason is that under Scenario 1, the short-term labor shortage in level-1 areas caused by a delayed return to work caused wages to rise by $1.85 \%$, which greatly affected labor-intensive manufacturing and service industries and resulted in a $0.77 \%$ decline in GRP. Looking at CPI, insufficient product supplies caused the CPI to increase in various regions. Under Scenario 2, a lack of labor and transportation controls led to insufficient supplies of products and higher prices. The CPI increased $1.24 \%$ in the level-1 areas and $0.93 \%$ in level-4 areas. The employment rate fell by $1.38 \%$ in the level-1 areas but was less affected in level-4 areas, falling by only $0.48 \%$. Household consumption decreased by approximately $2.5 \%$ in all areas. In Scenario 3, under the superimposed effects of labor shortages, transportation controls and changes in consumer demand, the impact of the epidemic changes from a consumption shock to business closures, decline in employment and an economic downturn. Taking the level- 1 areas as an example, GRP loss is about $0.8 \%$ and employment falls by $1.34 \%$. In addition, as the CPI increases, people's purchasing power declines. Scenario 4 simulates the economic impact of a decline in exports on production materials and industrial demand. The results show that exports of the level-1 areas fall by about $0.73 \%$, 
and levels $2-4$ areas experience a $0.28 \%$ fall in exports. Due to differences in the import and export volumes of provinces, the impact also differs. For example, the total import and export volumes of Shanghai and Chongqing are large, so the impact is relatively large.

Table 3 Rates of change in GRP, CPI, employment rate, household consumption, imports and exports under different COVID-19 containment scenarios (\%)

\begin{tabular}{|c|c|c|c|c|c|c|}
\hline $\begin{array}{l}\text { Macro } \\
\text { indicators }\end{array}$ & GRP & CPI & Employment & $\begin{array}{l}\text { Household } \\
\text { consumption }\end{array}$ & Imports & Exports \\
\hline & I. -0.768 & I . 1.101 & I . -1.387 & I . -2.575 & I. 0.142 & I . -0.935 \\
\hline \multirow[t]{3}{*}{ Level-1 areas } & II . -0.786 & II . 1.243 & II . -1.381 & II . -2.432 & II . -0.331 & II . -0.939 \\
\hline & III. -0.796 & III. 1.113 & III. -1.339 & III. -2.710 & III. -0.544 & III. -0.734 \\
\hline & IV. -0.810 & IV. 1.010 & IV. -1.347 & IV. -2.178 & IV. -0.686 & IV . -0.744 \\
\hline \multirow[t]{4}{*}{ Level-2 areas } & I . -0.546 & I . 0.910 & I . -1.045 & I . -2.577 & I . 0.035 & I . -0.644 \\
\hline & II . -0.546 & II . 0.979 & II . -1.044 & II . -2.514 & II . -0.036 & II . -0.629 \\
\hline & III. -0.514 & III. 1.004 & III. -0.881 & III. -2.408 & III. 0.100 & III. -0.456 \\
\hline & IV. -0.530 & IV. 0.897 & IV. -0.894 & IV. -1.860 & IV. -0.041 & IV. -0.465 \\
\hline \multirow[t]{4}{*}{ Level-3 areas } & I . -0.356 & I . 0.882 & I . -0.676 & I . -3.032 & I . 0.142 & I . -0.527 \\
\hline & II . -0.355 & II . 0.962 & II . -0.671 & II . -2.951 & II . 0.060 & II . -0.519 \\
\hline & III. -0.366 & III. 0.755 & III. -0.573 & III. -3.194 & III. 0.115 & III. -0.280 \\
\hline & IV. -0.378 & IV. 0.654 & IV. -0.581 & IV. -2.141 & IV. -0.010 & IV. -0.299 \\
\hline \multirow[t]{4}{*}{ Level-4 areas } & I . -0.236 & I . 0.870 & I . -0.479 & I . -3.073 & I . 0.342 & I . -0.417 \\
\hline & II . -0.240 & II . 0.929 & II . -0.478 & II . -3.021 & II . 0.267 & II . -0.394 \\
\hline & III. -0.284 & III. 0.647 & III. -0.402 & III. -3.380 & III. 0.256 & III. -0.077 \\
\hline & IV. -0.294 & IV. 0.549 & IV. -0.408 & IV. -2.216 & IV. 0.133 & IV. -0.091 \\
\hline
\end{tabular}

Note: I is impact scenario 1; II is impact scenario 2; III is impact scenario 3; and IV is impact scenario 4.

Source: TERM-China model simulation results

The simulations show that the epidemic affects both the supply side of production and the demand side of goods and services, with macroeconomic indicators, such as GRP and employment, being significantly affected. In the short term, unemployment increases and CPI rises. Given that the short-term static TERM-China model assumption does not consider the impact of capital accumulation, the main reason for the slowdown in GRP growth is employment. The COVID-19 epidemic leads to a decline in consumer demand and delays in returning to work, which causes assets of enterprises to depreciate, which in turn affects employment, lowers GRP growth, and influences private consumption and investment, government spending and trade. During the epidemic, people's long-term capacity to consume falls due to lower incomes, and the spread of the disease disturbs investment in capital markets. In addition, shrinking consumer demand in China increases exports of domestically produced goods, but exports also suffer. COVID-19 reduces the production efficiency of export companies in the short term, while increasing transaction costs and risks.

\subsection{Impacts of COVID-19 on industry}

Identifying the key industries and industrial chains affected by COVID-19 is the focus of targeted economic recovery policies. The simulation shows that in Scenario 1, the impact of 
the decline in labor supply on agriculture, forestry, animal husbandry, fisheries and food processing industries is relatively small, with a decline in output of $0.8 \%$, mainly due to the relatively small need for labor mobility in those industries. The output of labor-intensive industries such as textile and apparel processing, toy and furniture processing, and electronic equipment manufacturing, however, fall by $1.1 \%$ (Table 4 ), and the rental services sector by $0.7 \%$ (Table 5). Compared with Scenario 1, the impact of the COVID-19 on industry under Scenario 2, in which labor shortages and transportation controls are simultaneously influenced, only differs in level-1 areas, with little difference in other areas. Under Scenario 3, which combines the impacts of labor shortages, transportation controls and reduced consumer demand, the output of tertiary industry, which is dominated by service industries,

Table 4 Rates of change in output of major sectors of secondary industry under different COVID-19 containment scenarios $(\%)$

\begin{tabular}{|c|c|c|c|c|}
\hline Sector & Level-1 areas & Level-2 areas & Level-3 areas & Level-4 areas \\
\hline \multirow[t]{4}{*}{ Textiles } & I. -1.852 & I. -1.329 & I. -1.061 & I . -0.943 \\
\hline & II. -1.846 & II . -1.320 & II . -1.051 & II . -0.908 \\
\hline & III. -1.708 & III. -1.105 & III. -0.527 & III. -0.179 \\
\hline & IV. -1.744 & IV. -1.132 & IV. -0.563 & IV. -0.218 \\
\hline \multirow[t]{4}{*}{$\begin{array}{c}\text { Clothing, shoes, hats and leather and } \\
\text { down products }\end{array}$} & I. -1.283 & I . -1.105 & I. -0.896 & I . -0.732 \\
\hline & II . -1.134 & II . -1.066 & II . -0.860 & II . -0.662 \\
\hline & III. -1.244 & III. -0.935 & III. -0.432 & III. -0.054 \\
\hline & IV. -1.264 & IV. -0.959 & IV. -0.465 & IV. -0.086 \\
\hline \multirow[t]{4}{*}{ Wood products and furniture } & I. -1.316 & I . -0.981 & I . -0.712 & I. -0.600 \\
\hline & II . -1.303 & II. -0.972 & II. -0.708 & II . -0.577 \\
\hline & III. -1.356 & III. -1.025 & III. -0.585 & III. -0.352 \\
\hline & IV. -1.380 & IV. -1.045 & IV. -0.611 & IV. -0.379 \\
\hline \multirow[t]{4}{*}{$\begin{array}{l}\text { Papermaking, printing and cultural, } \\
\text { educational and sporting goods }\end{array}$} & I . -1.361 & I . -1.008 & I. -0.746 & I. -0.642 \\
\hline & II . -1.380 & II . -1.016 & II.-0.758 & II. -0.635 \\
\hline & III. -1.411 & III. -1.056 & III. -0.595 & III. -0.353 \\
\hline & IV. -1.437 & IV. -1.078 & IV. -0.621 & IV. -0.380 \\
\hline \multirow[t]{4}{*}{$\begin{array}{l}\text { Communication equipment, com- } \\
\text { puters and other electronic equipment }\end{array}$} & I . -1.291 & I . -1.152 & I . -0.957 & I . -0.790 \\
\hline & II . -1.259 & II. -1.157 & II . -0.962 & II . -0.785 \\
\hline & III. -1.281 & III. -1.123 & III. -0.850 & III. -0.638 \\
\hline & IV. -1.338 & IV. -1.168 & IV. -0.893 & IV. -0.662 \\
\hline \multirow[t]{4}{*}{ Instrumentation } & I . -1.128 & I . -0.954 & I . -0.804 & I . -0.719 \\
\hline & II . -1.154 & II . -0.965 & II . -0.819 & II . -0.730 \\
\hline & III. -1.130 & III. -0.927 & III. -0.700 & III. -0.593 \\
\hline & IV. -1.137 & IV. -0.936 & IV. -0.705 & IV. -0.590 \\
\hline \multirow[t]{4}{*}{ Other manufacturing products } & I . -1.385 & I . -0.880 & I . -0.730 & I . -0.602 \\
\hline & II . -1.409 & II . -0.876 & II . -0.728 & II . -0.590 \\
\hline & III. -1.436 & III. -0.895 & III. -0.652 & III. -0.488 \\
\hline & IV. -1.484 & IV. -0.921 & IV. -0.681 & IV. -0.511 \\
\hline
\end{tabular}

\footnotetext{
Note: I is impact Scenario 1; II is impact Scenario 2; III is impact Scenario 3; and IV is impact Scenario 4.
} 
Table 5 Rates of change in output of major sectors of tertiary industry under different COVID-19 containment scenarios $(\%)$

\begin{tabular}{|c|c|c|c|c|}
\hline Sector & Level-1 areas & Level-2 areas & Level-3 areas & Level-4 areas \\
\hline \multirow[t]{5}{*}{ Wholesale and retail } & I. -0.875 & I . -0.667 & I. -0.460 & I. -0.293 \\
\hline & II . -0.904 & II . -0.662 & II . -0.454 & II . -0.285 \\
\hline & III. -1.213 & III. -2.117 & III. -2.134 & III. -2.478 \\
\hline & IV. -1.226 & IV. -2.128 & IV. -2.146 & IV. -2.486 \\
\hline & I. -0.706 & I. -0.574 & I. -0.422 & I. -0.347 \\
\hline \multirow{3}{*}{$\begin{array}{c}\text { Transportation, storage and } \\
\text { postal services }\end{array}$} & II . -1.261 & II . -0.749 & II . -0.610 & II . -0.523 \\
\hline & III. -1.277 & III. -0.727 & III. -0.598 & III. -0.531 \\
\hline & IV.-1.293 & IV. -0.744 & IV. -0.613 & IV. -0.545 \\
\hline \multirow[t]{5}{*}{ Accommodation and catering } & I. -0.671 & I. -0.601 & I. -0.387 & I . -0.360 \\
\hline & II . -0.472 & II . -0.551 & II . -0.333 & II . -0.314 \\
\hline & III. -4.833 & III. -4.146 & III. -4.221 & III. -3.770 \\
\hline & IV. -4.827 & IV. -4.146 & IV. -4.218 & IV. -3.768 \\
\hline & I. -0.419 & I. -0.330 & I. -0.177 & I. -0.118 \\
\hline \multirow{3}{*}{$\begin{array}{l}\text { Information transmission, } \\
\text { software and IT services }\end{array}$} & II . -0.407 & II . -0.314 & II . -0.160 & II . -0.108 \\
\hline & III. 1.034 & III. 1.175 & III. 1.433 & III. 1.458 \\
\hline & IV. 1.034 & IV. 1.173 & IV. 1.433 & IV. 1.458 \\
\hline \multirow[t]{4}{*}{ Rental and Business Services } & I. -0.927 & I. -0.840 & I. -0.582 & I. -0.514 \\
\hline & II . -0.970 & II . -0.858 & II . -0.605 & II . -0.529 \\
\hline & III. -1.053 & III. -1.020 & III. -0.721 & III. -0.650 \\
\hline & IV. -1.054 & IV. -1.029 & IV. -0.724 & IV. -0.655 \\
\hline \multirow[t]{4}{*}{ Health and social work } & I. -0.180 & I. -0.139 & I. -0.026 & I . 0.018 \\
\hline & II . 0.144 & II . -0.049 & II . 0.070 & II . 0.100 \\
\hline & III. 10.606 & III. 9.281 & III. 9.406 & III. 8.736 \\
\hline & IV. 10.610 & IV. 9.283 & IV. 9.411 & IV. 8.740 \\
\hline \multirow[t]{4}{*}{ Culture, sports and entertainment } & I. -0.610 & I. -0.717 & I. -0.471 & I. -0.390 \\
\hline & II . -0.425 & II . -0.702 & II . -0.447 & II . -0.367 \\
\hline & III. -3.472 & III. -2.346 & III. -2.324 & III. -2.024 \\
\hline & IV. -3.457 & IV. -2.341 & IV. -2.316 & IV. -2.016 \\
\hline
\end{tabular}

Note: I is impact Scenario 1; II is impact Scenario 2; III is impact Scenario 3; and IV is impact Scenario 4.

shows a large decline. For example, accommodation and catering decline by about $4 \%$ compared to Scenario 2, and entertainment falls by about $2.5 \%$. The IT and medical and health industries both see slight increases. In Scenario 4, export-oriented industries, such as textiles and toy manufacturing, are significantly affected, with declines of about $0.7 \%$.

In general, COVID-19 has had a big impact on the service industry, which is dominated by consumer industries, and has had a certain impact on labor-intensive manufacturing industries and some upstream and downstream manufacturing industries, such as textile and apparel production, automobile manufacturing and electronics manufacturing. At the same time, the epidemic has brought development opportunities for the development of some industries, such as medical and health as well as information transmission, software and IT services.

Risk levels and the distribution of industries in China differ by region, so the impact of the COVID-19 epidemic on industry shows large spatial differences. Hubei Province is a component processing base in the global electronic equipment and automobile manufactur- 
ing supply chains, and it enjoys competitive advantages in automobile equipment manufacturing, electronic information and textiles. The epidemic caused work stoppages that impacted those industries. The simulation shows that under Scenario 4, various industries in Hubei Province suffer significant damage, particularly the electronic equipment manufacturing, transportation equipment manufacturing, textiles, accommodation and catering, and entertainment industries, with output value losses of $1.14 \%, 1.14 \%, 1.74 \%, 4.83 \%$ and $3.46 \%$, respectively. The surrounding areas of Hubei and destinations for migrant workers from Hubei, such as Guangdong, Zhejiang, Henan and other local industries, are greatly affected by the epidemic. The textile and furniture manufacturing industries in Guangdong and Zhejiang are particularly affected. Textile manufacturing falls $1.23 \%$, and electronic equipment manufacturing falls $1.07 \%$. Service industries in level-2 areas account for a relatively large proportion, with upstream industries hit by the decline in front-end consumer demand. For example, a reduction in consumer demand in the catering industry in Henan Province results in a loss of about $0.95 \%$ in the output value of upstream food processing industries. In Beijing and Shanghai, which are dominated by tertiary industry, delays in returning to work, shortages of labor and capital operational difficulties lead to losses of $1.1 \%$ in the rental industry and $3.56 \%$ in accommodation and catering. Secondary and tertiary sectors in level-4 areas are relatively underdeveloped, so industries there are less affected by COVID-19. In agriculture, the livestock industry is relatively affected. For example, the output values of agriculture, forestry, animal husbandry and fisheries, and food processing in Ningxia Hui Autonomous Region fall significantly, by about $0.8 \%$.

The COVID-19 epidemic has also led to the development of some industries, such as information transmission, software and IT services. Under Scenario 3, for example, the output value of health and social management increases by nearly $9.13 \%$, and the output value of information transmission, software and IT services increases by nearly $1.36 \%$. Level-2 areas, whose industrial structure is dominated by tertiary industry and have developed information industries, are most affected. The output values of the information transmission, software and IT service industries in those areas increase by about $1.18 \%$. In addition, the epidemic stimulates the development of the health industry in areas of levels $1-2$, with output values of the medical industry increasing by $10.6 \%$ and $9.28 \%$, respectively.

\subsection{Adaptative scenario simulations}

This study selects return to work and production and proactive fiscal policies to carry out adaptive scenario simulations. In the resumption of work and production scenario, compared with Scenario 4, GDP rebounds by nearly $0.14 \%$, employment increases $0.3 \%$, and prices drop $0.4 \%$. From a regional perspective, although level-4 areas returned to work and resumed production earlier, because of the relatively small impact of the epidemic, the effect on GRP growth is about $0.1 \%$, but in areas of levels $2-3$, which resumed work later than level-4 areas, the effect is about $0.2 \%$ (Figure 5). Areas of levels $2-3$ are dominated by labor-intensive industries, and the resumption of work and production was mainly by increasing labor supply. The economic recovery of those areas had a strong propulsive effect. The GRP of Hubei, the most severely affected area, recovered by $0.3 \%$, but the greater impact and lag in returning to work and resuming production means it will take longer for its economy to recover compared to other regions. The return to work and production improved 
the output of all industries to a certain extent, especially labor-intensive manufacturing and service sectors in areas of levels 2-3 (Figure 6).

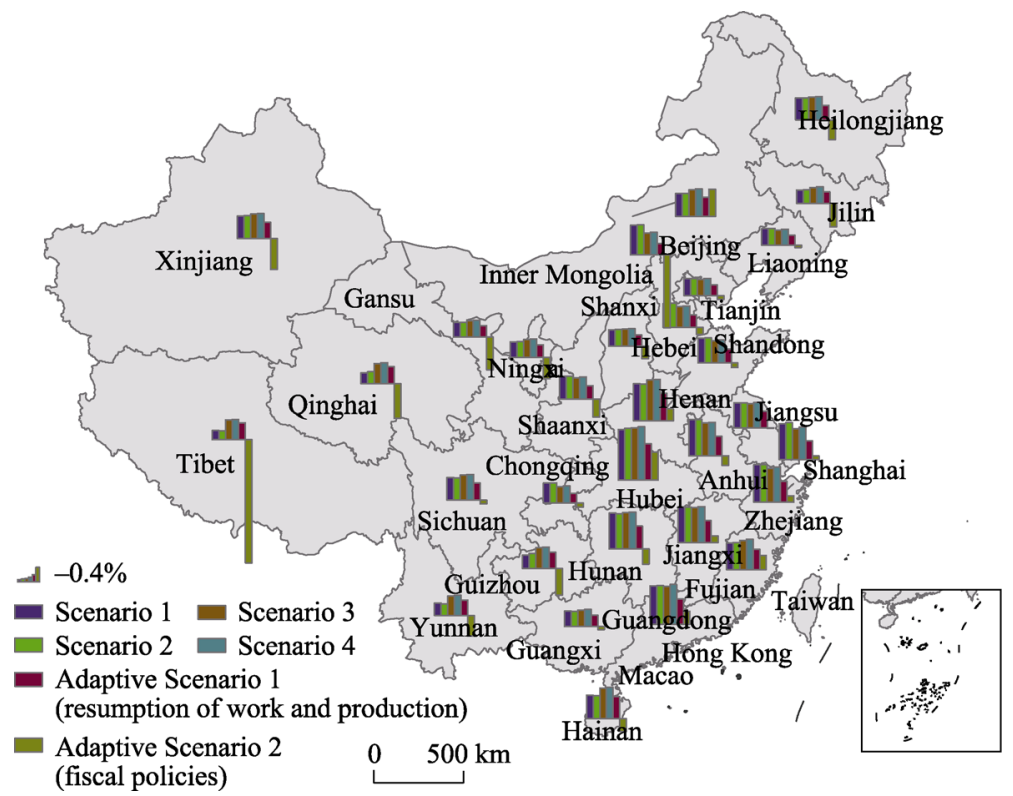

Figure 5 Rates of change in GRP of each province under different COVID-19 epidemic containment scenarios

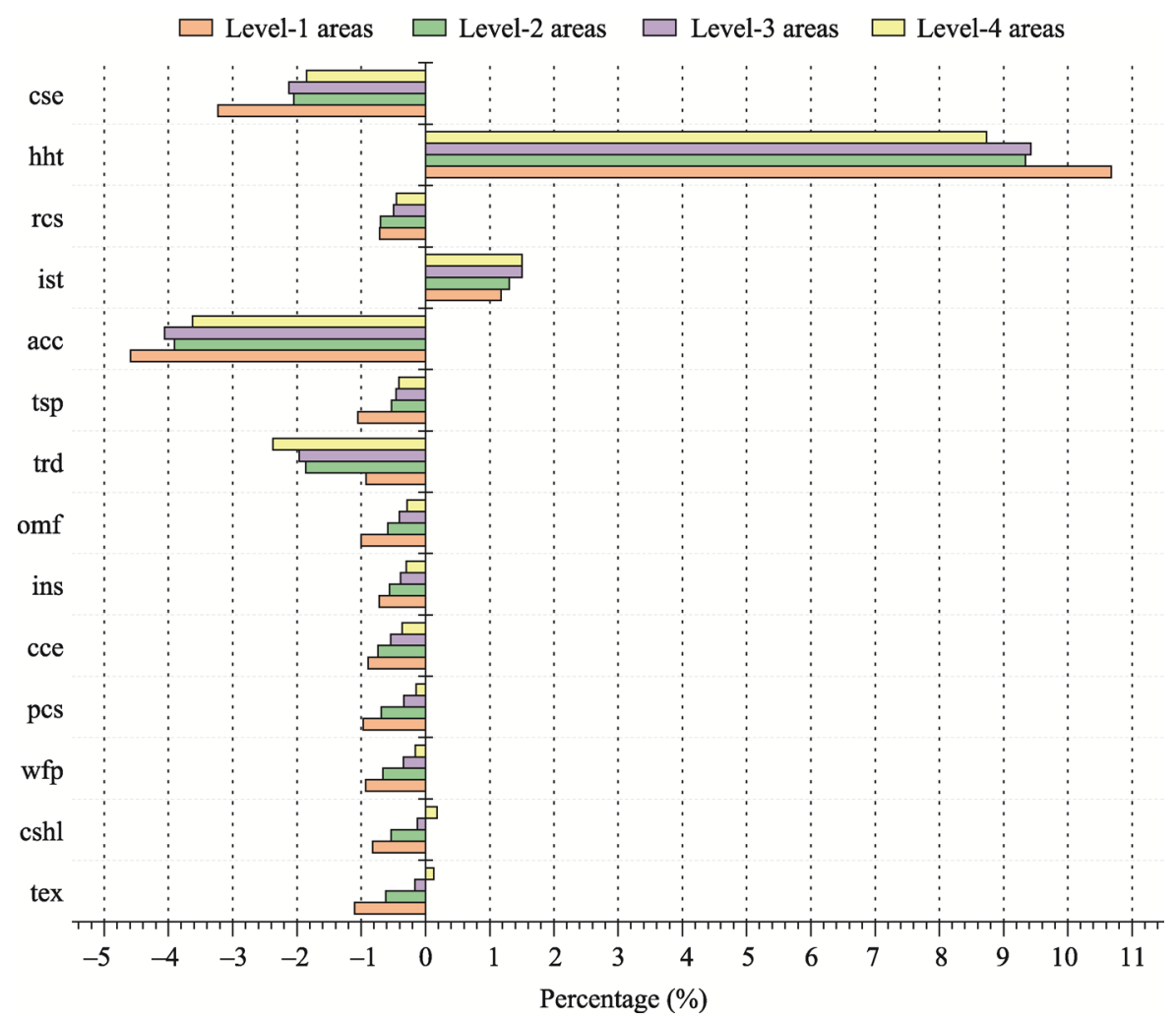

Figure 6 Rates of change in output of major sectors of regions with different COVID-19 risks under adaptive scenario 1 
An increase in the proportion of household consumption in the structure of final demand leads to an increase in fiscal expenditure and a reduction in the contribution of economic growth. Under the adaptive scenario of increased fiscal expenditure, GRP increases by about $0.5 \%$ compared with Scenario 4 , while the CPI rises by about $1.8 \%$. If government spending increases, competition for purchases in commodity markets intensifies, and prices rise. Comparing the two adaptive scenarios, implementing capital stimulus policies is more advantageous. Under an expansionary fiscal policy, government expenditure increases, which increases aggregate demand and intensifies competition over the purchase of products and labor services in commodity markets, so prices rise significantly. Although this policy model can increase aggregate public demand in the short term, it needs to be implemented cautiously in combination with monetary policy, and specific deficit ratios should be determined according to the impact of COVID-19 in different regions to reduce the risk of inflation. Based on the model hypothesis, the main reason for the increase in GRP due to an increase in government expenditure is improved employment. The results show that compared with Scenario 4 , the employment rate increases by nearly $1.1 \%$. At industry level, an increase in fiscal expenditure mainly contributes to growth in output of the tertiary sector, including the public management and social security industries. Compared with a rapid resumption of work and production, the radial effect of increasing fiscal expenditure to stimulate industrial recovery is smaller, and the former benefits a wider range of industries (Figure 7).

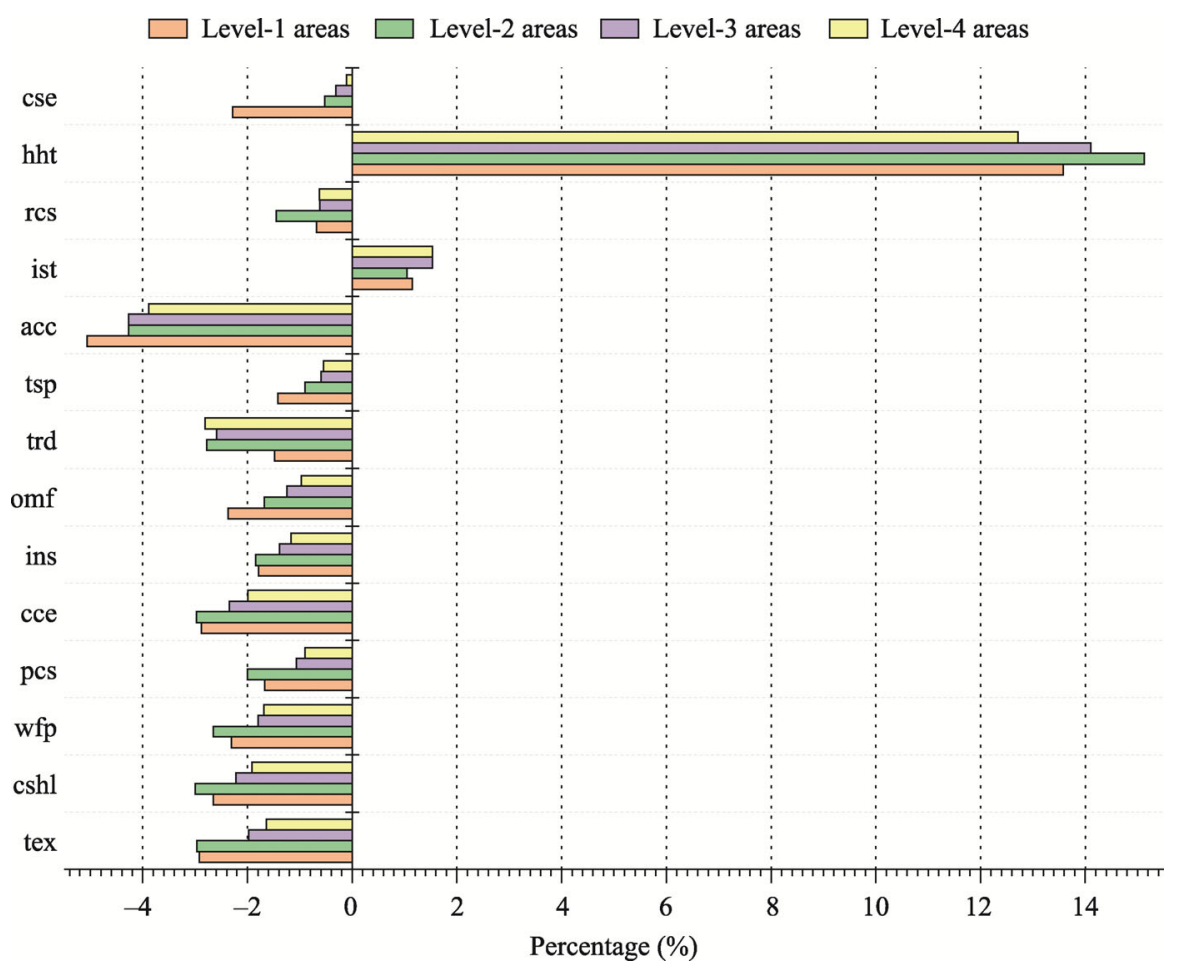

Figure 7 Rates of change in output of major sectors of regions with different COVID-19 risks under adaptive scenario 2

Note: cse-Culture, sports and entertainment; hht-Health and social work; rcs-Rental and commercial services; ist-Information transmission, software and IT services; acc-Accommodation and catering; tsp-Transportation, storage and postal services; trd-Wholesale and retail; omf-Other manufacturing products; ins-Instrumentation; cce-Communication equipment, computers and other electronic equipment; pcs-Papermaking, printing and cultural and sporting goods; wfp-Wood products and furniture; cshl-Clothing, shoes, hats and leather and down products; tex-Textiles 


\section{Conclusions and discussion}

This study is based on a refined multi-regional computable general equilibrium analysis model for China - TERM-China, which simulates the impacts of the COVID-19 epidemic on China's economic system and industrial sectors, as well as its economic and industrial recovery when different adaptive measures are applied. The results show that changes in total consumer demand and the consumption model caused by COVID-19 lead to a short-term decline in consumption, investment, and employment, as well as a rise in prices. Delayed resumption of work and production and transportation controls reduce labor input, causing labor wages to rise, enterprise production costs to increase and supply to fall. In addition, COVID-19 affects international trade through its impact on global production supply chains.

Simulations show that China's economic development is resilient, and the epidemic causes trending changes. Since the outbreak of COVID-19, China has introduced macroeconomic policies to boost the economy and increased investment in public healthcare to control the disease. Although COVID-19 will have an impact on China's economy in the short term, if the government can effectively contain the epidemic and reduce the duration of its effects, this will effectively ease any pressures.

A systematic analysis of measures to get people back to work and resume production adopted at the national and regional levels can help improve relevant policies. Both virus containment and economic recovery efforts need to be implemented according to the principle of being "top-down". At the national level, it is necessary to identify key industries affected by COVID-19, and a stable yet flexible monetary policy should be employed to reduce short-term operating costs. Countercyclical adjustments to fiscal policies can also be used to expand fiscal expenditure. At the regional level, the impact of COVID-19 on consumption channels is more rapid and direct and is transmitted to upstream manufacturing. As such, while paying attention to the direct impacts of the epidemic on industries, it is also necessary to pay attention to indirect impacts on industries through the supply chain. At the enterprise level, it is necessary to provide practical assistance based on actual production needs, as well as to improve supervision, stabilize employment and protect people's livelihoods while easing regulation.

This study only simulates the economic impact of COVID-19 in China and lacks global market equilibrium analysis. This means that the falls in the macroeconomic results are smaller than those in existing research and published data. Taking GDP as an example, most studies have shown that the epidemic may reduce China's economic growth by about $1 \%$ to 2\% in 2020 (Wen et al., 2020; Barichello, 2020; Zhou et al., 2020). According to published data on the national economy in July 2020, GDP fell in the first half of the year by $1.6 \%$ year-on-year. The results of this study, meanwhile, show that the GRP of each province, municipality and autonomous region fell by between $0.4 \%$ and $0.8 \%$ in 2020 compared to normal conditions. In addition, this simulation does not consider dynamic trends in the epidemic situation on a global scale or include analysis of global industrial supply chains, so the degree of economic shock it reflects is relatively minor. Future research should create a global general equilibrium model to analyze the different impacts of COVID on the global economy, to serve as a more accurate reference source. 


\section{References}

Anand K, Pandav C S, Nath L M, 1999. Impact of HIV/AIDS on the national economy of India. Health Policy, 47(3): 195-205.

Barichello R, 2020. The COVID-19 pandemic: Anticipating its effects on Canada's agricultural trade. Canadian Journal of Agricultural Economics, 68(2): 219-224.

Binder C, 2020. Coronavirus fears and macroeconomic expectations. Available at SSRN: https://ssrn.com/abstract= 3550858 .

Cuddington J T, Hancock J D, 1995. The macroeconomic impact of AIDS in Malawi: A dualistic, labour surplus economy. Journal of African Economies, 4(1): 1-28.

Deb P, Furceri D, Ostry J D et al., 2020. The economic effects of Covid-19 containment measures. Available at SSRN: https://ssrn.com/abstract $=3661431$.

Dixon P B, Lee B, Muehlenbeck T et al., 2010. Effects on the US of an H1N1 epidemic: Analysis with a quarterly CGE model. Journal of Homeland Security and Emergency Management, 7(1): 1547-7355.

Dixon S, McDonald S, Roberts J, 2002. The impact of HIV and AIDS on Africa's economic development. British Medical Journal, 324(7331): 232-234.

Dixon P, Rimmer M T, 2010. Simulating the US recession with and without the Obama package: The role of excess capacity. Melbourne: The Centre of Policy Studies (CoPS).

Duan H, Wang S, Yang C, 2020. Coronavirus: Limit short-term economic damage. Nature, 578(7796): 515.

Geoffard P Y, Philipson T, 1996. Rational epidemics and their public control. International Economic Review, 37(3): 603-624.

Gohin A, Rault A, 2013. Assessing the economic costs of a foot and mouth disease outbreak on Brittany: A dynamic computable general equilibrium analysis. Food Policy, 39: 97-107.

He Chengying, Wen Yuechun, Chang Yali et al., 2020. Measurement and Analysis of the COVID-19 epidemic impact on China's economy. The Journal of Quantitative \& Technical Economics, 37(5): 3-22. (in Chinese)

Horridge M, 2012. The TERM model and its database. Economic Modeling of Water, 13-35.

Horridge M, Wittwer G, 2008. SinoTERM, a multi-regional CGE model of China. China Economic Review, 19(4): $628-634$.

Huang Yiping, 2020. Economic impact of new coronary pneumonia and policy responses. Enterprise Observer, (1): 76-77. (in Chinese)

Jiang Ling, Zhang Wei, Liu Yu, 2016. Assessment of indirect economic loss of flood disaster based on multiregional CGE model: A case of Yangtze River Delta basin. Management Review, 28(6): 25-31. (in Chinese)

Kambou G, Devarajan S, Over M, 1992. The economic impact of AIDS in an African country: Simulations with a computable general equilibrium model of Cameroon. Journal of African Economies, 1(1): 109-130.

Keogh-Brown M R, Smith R D, Edmunds J W et al., 2010. The macroeconomic impact of pandemic influenza: Estimates from models of the United Kingdom, France, Belgium and The Netherlands. The European Journal of Health Economics, 11(6): 543-554.

KPMG China, 2020. The impact of Covid-19 on China's macro economy. http://www.china-cer.com.cn/hongguanjingji/202002072162.html. (in Chinese)

Lee G O M, Warner M, 2006. Human resources, labour markets and unemployment: The impact of the SARS epidemic on the service sector in Singapore. Asia Pacific Business Review, 12(4): 507-527.

Lee J W, McKibbin W J, 2004. Globalization and disease: The case of SARS. Asian Economic Papers, 3(1): $113-131$.

Lenzen M, Li M, Malik A et al., 2020. Global socio-economic losses and environmental gains from the Coronavirus pandemic. PloS One, 15(7): e0235654.

Li Huizhi, Yi Dali, Li Gaoming, 2020. Comparative study on assessment methods of epidemic risk of COVID-19 in Chongqing. Journal of Chongqing Medical University, 45(7): 870-875. (in Chinese)

McKibbin W J, Sidorenko A, 2006. Global macroeconomic consequences of pandemic influenza. Sydney: Lowy Institute for International Policy.

McKibbin W J, Fernando R, 2020. The global macroeconomic impacts of COVID-19: Seven scenarios. Available at SSRN: https://ssrn.com/abstract=3547729.

Nicola M, Alsafi Z, Sohrabi C et al., 2020. The socio-economic implications of the coronavirus pandemic (COVID-19): A review. International Journal of Surgery, 78: 185-193.

Roos E, 2013. Modelling the impact of HIV/AIDS: A literature review. Melbourne: The Centre of Policy Studies 
(CoPS).

Sachs J, 2001. Macroeconomics and health: Investing in health for economic development. Geneva: World Health Organization.

Shao S, 2020. Analysis of China's novel coronavirus pneumonia epidemic based on previous PHEIC events. International Invention of Scientific Journal, 4(3): 1008-1015.

Siu A, Wong Y C R, 2004. Economic impact of SARS: The case of Hong Kong. Asian Economic Papers, 3(1): $62-83$.

Smith R D, Keogh - Brown M R, 2013. Macroeconomic impact of a mild influenza pandemic and associated policies in Thailand, South Africa and Uganda: A computable general equilibrium analysis. Influenza and Other Respiratory Viruses, 7(6): 1400-1408.

Smith R D, Keogh-Brown M R, Barnett T, 2011. Estimating the economic impact of pandemic influenza: An application of the computable general equilibrium model to the UK. Social Science \& Medicine, 73(2): 235-244.

Smith K M, Machalaba C C, Seifman R et al., 2019. Infectious disease and economics: The case for considering multi-sectoral impacts. One Health, (7): 100080.

Sun Jiuwen, 2020. The impact of the new crown pneumonia epidemic on China's regional economic development. Regional Economic Review, (2): 8-11. (in Chinese)

Tang Wenjin, Liao Rongrong, Liu Jing, 2009. A review of studies on the economic impact of public emergencies. Economic Perspectives, (4): 112-116. (in Chinese)

Tu Hongwei, Zhong Ruoxi, Xiao Jianpeng et al., 2020. Region and risk-specific strategies for coronavirus disease 2019 epidemic control and prevention in Guangdong province: A risk assessment study. Chinese Journal of Public Health, 36(4): 486-492. (in Chinese)

Verikios G, McCaw J, McVernon J et al., 2010. H1N1 influenza in Australia and its macroeconomic effects. Melbourne: The Centre of Policy Studies (CoPS).

Verikios G, Sullivan M, Stojanovski P et al., 2011. The global economic effects of pandemic influenza. Melbourne: The Centre of Policy Studies (CoPS).

Wang Wei, Li Zimo, Wang Xiaowei, 2017. Research on the industrial synergetic development pattern of the Yangtze River Economic Belt. Modernization of Management, 37(1): 23-25. (in Chinese)

Wang Ruolan, 2020. The impact of the new crown pneumonia epidemic on the global economy and its response strategies: Based on the perspective of global production supply chains. International Finance, (4): 31-36. (in Chinese)

Wen Yun, Zhang Tao, Du Qianyi, 2020. Quantifying the Covid-19 economic impact. Available at SSRN: https://ssrn.com/abstract=3546308. (in Chinese)

Xie Wei, Li Ning, Hu Aijun et al., 2012. Assessing the economic impact of environmental disaster: A computable general equilibrium analysis. China Population, Resources and Environment, 22(11): 26-31. (in Chinese)

Xie W, Li N, Wu J et al., 2013. Modeling economic costs of disasters and recovery involving positive effects of reconstruction: Analysis using a dynamic CGE model. Natural Hazards and Earth System Sciences Discussions, 1(6): 6357-6398.

Yang H Y, Chen K H, 2009. A general equilibrium analysis of the economic impact of a tourism crisis: A case study of the SARS epidemic in Taiwan. Journal of Policy Research in Tourism, Leisure and Events, 1(1): $37-60$.

Zeng Chunyuan, Feng Yan, 2004. Viewing of the strength of the national economy for fighting against crisis from the case of SRAS. Journal of Beijing Institute of Technology (Social Sciences Edition), 6(4): 13-15. (in Chinese)

Zhou Meifang, Liu Yu, Zhang Jinzhu et al., 2020. Research on the macroeconomic effects of the new crown pneumonia epidemic and the effectiveness of response policies. Quantitative Economics and Technical Economics Research, 37(8): 24-41. (in Chinese)

Zhou Jian, 2020. The impact of the new crown pneumonia epidemic on the transportation industry and policy recommendations. Transportation Research, 6(1): 13-18. (in Chinese)

Zhou Yiming, Jiang Cailiang, 2020. Comparison and analysis of influence of SARS and COVID-19 on passenger and freight transportation in China. Transport Research, 6(1): 24-32. (in Chinese)

Zhu Kunfu, Gao Xiang, Yang Cuihong et al., 2020. The COVID-19 shock on global production chains and risk of accelerated China's industrial chains outflow. Bulletin of Chinese Academy of Sciences, 35(3): 283-288. (in Chinese) 